\title{
Soil Physical Quality in Sugarcane Field Under Cover Crop and Different Soil Tillage Systems
}

\author{
C. V. V. Farhate ${ }^{1}$, Z. M. Souza ${ }^{1}$, W. S. Guimarães Jr. ${ }^{2}$, A. C. M. Sousa ${ }^{3}$, M. C. C. Campos ${ }^{4}$ \& J. L. N. Carvalho \\ ${ }^{1}$ School of Agricultural Engineering, University of Campinas, Campinas, São Paulo, Brazil \\ ${ }^{2}$ Center for Research and Development in Soil and Environmental Resources, Agronomic Institute of Campinas, \\ Campinas, São Paulo, Brazil \\ ${ }^{3}$ Federal Institute Catarinense, Campus Videira, Videira, Santa Catarina, Brazil \\ ${ }^{4}$ Institute of Education, Agriculture and Environment, University of Amazonas, Campus Vale do Rio Madeira, \\ Humaitá, Amazonas, Brazil \\ 5 Brazilian Center for Research in Energy and Materials_-Brazilian Bioethanol Science and Technology, \\ Campinas, São Paulo, Brazil
}

Correspondence: C. V. V. Farhate, School of Agricultural Engineering, University of Campinas, Av. Cândido Rondon, 501, Barão Geraldo, Campinas, São Paulo, Brazil. Tel: 55-199-8402-0683. E-mail: camilavianav@hotmail.com

$\begin{array}{lr}\text { Received: June 15, } 2018 & \text { Accepted: August 31, 2018 Online Published: October 15, } 2018 \\ \text { doi:10.5539/jas.v10n11p489 } & \text { URL: https://doi.org/10.5539/jas.v10n11p489 }\end{array}$

The research is financed by São Paulo Research Foundation (grant numbers: 2013/21696-3).

\begin{abstract}
Currently, the management practices employed in Brazilian sugarcane plantations have contribute to soil physical degradation and, few studies considering the effect of cover crop associated with conservationist soil tillage systems to control or even reverse this process. Therefore, with the aim to assess the impact of cover crop and tillage systems on the least limiting water range (LLWR) and the S index in two soils of different textures used for sugarcane production, a fieldwork was carried out in two sugarcane plantations in the state of São Paulo, Brazil. The experimental design is a split-plot with four repetitions. The main factor consisted of soil cover vegetation: cover crop and fallow, and the second factor, the tillage system: minimum tillage and conventional tillage. The data of this study demonstrated that clayey and medium-textured soil are sensitive to the management systems used. The use of cover crop promoted an increase of LLWR (average incremental rate of 105\% for clayey and $100 \%$ for medium-textured soil) and S index (average incremental rate of $16 \%$ for clayey and $10 \%$ for medium-textured soil). The maintenance of soil under fallow represented restrictive conditions for the growth/development of the plants due to the degradation of the soil structure. In addition, conservation management systems, such as minimum tillage, resulted in better soil physical quality when associated with cover crop. Finally, the clayey and medium-textured soil, show good $\mathrm{S}$ index during the first cycle of sugarcane cultivation.
\end{abstract}

Keywords: least limiting water range, $\mathrm{S}$ index, sugarcane replanting, minimum tillage, conventional tillage, conservation management systems, soil degradation

\section{Introduction}

Sugarcane cultivation was introduced in Brazil since the colonial period (between the XVI and XIX centuries) and presents a highlight position in the national economy due to the planted area, nine million hectares (Conab, 2018), which generate directly and indirectly millions of jobs (Neves \& Trombina, 2014) and energy potential (Cortez, 2010).

However, sugarcane monoculture, intensive soil tillage, and machinery in-field traffic lead to accelerated soil physical degradation. Conversely, the use of conservation management systems, such as minimum tillage and no-tillage, can help maintaining soil productivity since crop residues are left on the soil surface under both systems, and tillage is minimal and/or restricted to planting rows. Moreover, both systems emphasize the use of cover crop, which improve soil quality conditions. 
Some soil physical properties, such as bulk density, porosity, penetration resistance and available water are used to characterize soil physical status and to assess the effectiveness of different management systems. Soil physical properties evaluated individually, however, cannot fully explain changes of soil physical conditions - as it can be obtained by a combination of a certain number of them (Silva \& Kay, 1997; Tormena, Silva, \& Libardi, 1998; Guedes Filho, Blanco-Canqui, \& Silva, 2013).

In an attempt to integrate and simplify monitoring of soil physical quality, various authors have used the least limiting water range (LLWR) as an indicator of soil structural quality (Araújo et al., 2013; Gonçalves et al., 2014; Guimarães Júnnyor et al., 2015) and to evaluate the impact of several soil management practices (Tormena et al., 1998; Tormena et al., 2007). The LLWR is defined as the range of soil water content in which limitations to plant root growth correlated with water potential, aeration and mechanical resistance are minimal (Silva \& Kay, 1997). Conceptually, the LLWR comprises three factors - soil aeration, soil water retention and soil penetration resistance - that affect plant growth in a single variable. It is used as an indicator of soil structural quality for crop production and as a parameter to characterize the impact of soil management practices on sustainable productivity of soils (Silva et al., 1994).

The $\mathrm{S}$ index, defined as the slope of soil water retention curve at its inflection point, is directly related to microstructural porosity of soil. It expresses direct effects of soil management system on soil compaction, soil organic matter and root growth. Therefore, more structural pores are associated with higher $\mathrm{S}$ index, which is a desirable trait of a good soil (Dexter, 2004).

Many studies have demonstrated the efficiency of the LLWR and the S index to assess soil physical quality (Dexter, 2004; Leão et al., 2006; Andrade \& Stone, 2009; Cavalieri et al., 2011; Betioli Júnior et al., 2012; Gonçalves et al., 2014; Lima et al., 2012). However, only few studies have evaluated the effect of the use of cover crop associated with conservationist soil tillage systems to optimize LLWR and the S index.

We hypothesized that the adoption of cover crop together with minimum tillage during the sugarcane crop reformation period can improve soil physical indicators compared to conventional tillage system with fallow. Therefore, the objective of the study was to assess the impact of cover crop and tillage systems on the LLWR and the $\mathrm{S}$ index in two soils of different textures used for sugarcane production.

\section{Materials and Methods}

\subsection{Study Area}

The experiment was carried out in Iracema sugarcane mill, and Santa Fé sugarcane mill, located in Iracemápolis and Nova Europa in the state of São Paulo, respectively. The sites were chosen because the mills are under different edaphoclimatic conditions (Table 1). The soil of Iracema mill was classified as a Rhodic Hapludox (Soil Survey Staff, 2014), with clayey texture according to the texture classification scheme of the Department of Agriculture of the USA (USDA, 2017). The soil of Santa Fé mill was classified as a Typic Hapludox, whit texture medium-textured, according to the same classification systems.

\subsection{Materials}

For the planting of the cover plant, it was used Crotalaria juncea (sunn hemp), IAC KR1, at the dose of $25 \mathrm{~kg} \mathrm{ha}^{-1}$, seeded in rows, spaced every $0.5 \mathrm{~m}$ (Table 1 ). The fallow area, during the development of the cover crop, was subject to twinning of spontaneous species, which was supported by the "seed bank" present in the area.

During the sugarcane planting in the clayey soil, it was 36,69 and $69 \mathrm{~kg} \mathrm{ha}^{-1}$ of the N-P-K, respectively. In he medium-textured soil, 25, 125 and $115 \mathrm{~kg} \mathrm{ha}^{-1}$ of the N-P-K were respectively applied in the planting furrows based on the soil analysis performed prior to the experiment installation.

In both areas, the sunn hemp was desiccated and cutting at $0.05 \mathrm{~m}$ height. In the clayey soil area this operation was carried out by a tractor Case, model MXM $4 \times 4,110 \mathrm{~kW}$ and a strimmers Agritecha. In the medium-textured soil, a tractor Massey Ferguson, model Advanced $2754 \times 2,202 \mathrm{~kW}$ and a strimmers Agritecha were used.

The same treatments were implanted in both areas. For the clayey soil, the conventional tillage plots were prepared through two light harrows using a 36-disc hydraulic grid from Baldan and tractor Case, model MXM, $147 \mathrm{~kW}$ and, furrowing at $0.30 \mathrm{~m}$ depth using a tractor Valtra, model BH $1804 \times 4,134 \mathrm{~kW}$ and a furrow Driade of two lines. In the medium-textured soil, the equipment'sharrow Santa Izabel with 44-disc and a tractor Valtra, model BT $2104 \times$ $4,154 \mathrm{~kW}$. In the plots of minimum tillage, both clayey and medium-textured soil, only the furrowing at $0.30 \mathrm{~m}$ depth occurred in which it was used the same equipment used in conventional tillage in each of the respective sites.

For the planting of sugarcane, the stalks were distributed manually in the planting furrows, cut into smaller pieces and later with the aid of a machine, the planting furrows were covered. In the clayey soil was used cover machine 
of two lines and a tractor Massey Ferguson, model Advanced $2754 \times 2,202 \mathrm{~kW}$. In the medium-textured soil, was used cover machine DMB also two lines and a tractor New Holland, model TL85E, $65 \mathrm{kWv}$ to cover the planting furrow.

\subsection{Experimental Design}

The experimental design is a split-plot with randomized blocks in which the main factor corresponded to the soil cover vegetation: cover crop and fallow whereas second factor was tillage system: conventional tillage and minimum tillage. In this way, the following treatments combinations were analyzed in this study: i) cover crop with conventional tillage (CCCT); ii) fallow with conventional tillage (FCT); iii) cover crop with minimum tillage (CCMT); iv) fallow with minimum tillage (FMT).

Overall, the experimental area consisted of 16 experimental plots i.e. 4 treatments $\times 4$ replications. Each plot consisted of 15 sugarcane rows. Rows were $34 \mathrm{~m}$ long and $1.5 \mathrm{~m}$ between consecutive rows. Both sites received the same treatments whereby plots with conventional tillage were made with double harrowing $(0.40 \mathrm{~m}$ depth) and furrowing $(0.30 \mathrm{~m} \mathrm{depth})$, and plots with minimum tillage were only furrowed. Sugarcane planting was carried out manually in both experimental sites. Data regarding sunn hemp planting and desiccation, dry-matter (DM) production, sugarcane planting date, fertilization and sugarcane variety are presented in Table 1.

Table 1. Location, edaphoclimatic characteristics of the sites and activities in Iracemápolis (Iracema Mill) and Nova Europa (Santa Fé Mill)

\begin{tabular}{lll}
\hline \multirow{2}{*}{ Characteristics/Activities } & \multicolumn{2}{c}{ Site } \\
\cline { 2 - 3 } & Iracema Mill & Santa Fé Mill \\
\hline Soil texture & Clayey soil & Medium-textured soil \\
Geographical coordinates & $22^{\circ} 34^{\prime} \mathrm{S}$ and $47^{\circ} 31^{\prime} \mathrm{W}$ & $21^{\circ} 46^{\prime} \mathrm{S}$ and $48^{\circ} 33^{\prime} \mathrm{W}$ \\
Altitude (m) & 608 & 490 \\
Average annual precipitation (mm) & 1,420 & 1,311 \\
Köppen climate classification & $\mathrm{Cwa}$ & Aw \\
Soil classification (soil taxonomy system) & Rhodic Hapludox & Tipic Hapludox \\
Planting of sunn hemp & 22.01 .2013 & 22.02 .2014 \\
Desiccation of sunn hemp & 04.04 .2013 & 24.04 .2014 \\
Planting of sugarcane & 26.04 .2013 & 01.05 .2014 \\
Cultivated variety & $\mathrm{RB} \mathrm{96-6928}$ & $\mathrm{RB} 86-7515$ \\
Fertilization of sugarcane & $300 \mathrm{~kg} \mathrm{ha}^{-1}(12-23-23)$ & $500 \mathrm{~kg} \mathrm{ha} \mathrm{h}^{-1}(05-25-23)$ \\
\hline
\end{tabular}

Note. $\mathrm{CWa}=$ humid temperate; $\mathrm{Aw}=$ megathermal or tropical wet.

The experiments started with mechanical elimination of the ratoons and subsoiling to a depth of $0.40 \mathrm{~m}$. Subsoiling was necessary because a compacted layer was detected in the profile, which could have limited root growth in the subsequent cycle. The experiment on clayey soil started in 2013 and on medium-textured soil in 2014, and both sites were collected soil samples at the beginning of the experiment, to characterize the physical attributes of the area (Table 2).

Table 2. Physical properties of soils collected from clayey soil site and medium-textured soil site before the experiment

\begin{tabular}{lllllllll}
\hline Depth & Sand & Silt & Clay & Mac & Mic & Bd & PR & $\boldsymbol{\theta}$ \\
\hline$-\begin{array}{l}\text { Clayey soil } \\
0.00-0.10\end{array}$ & 148 & 206 & 646 & 0.11 & 0.44 & 1.38 & 0.90 & 0.30 \\
$0.10-0.20$ & 145 & 189 & 666 & 0.12 & 0.45 & 1.37 & 1.62 & 0.30 \\
$0.20-0.40$ & 126 & 188 & 686 & 0.19 & 0.39 & 1.27 & 1.66 & 0.32 \\
\hdashline Medium-textured soil & & & & & & & \\
$0.00-0.10$ & 820 & 36 & 144 & 0.16 & 0.17 & 1.67 & 1.09 & 0.14 \\
$0.10-0.20$ & 791 & 48 & 161 & 0.18 & 0.17 & 1.61 & 1.56 & 0.15 \\
$0.20-0.40$ & 788 & 44 & 168 & 0.16 & 0.18 & 1.51 & 1.64 & 0.17
\end{tabular}

Note. Mac $=$ Macroporosity $;$ Mic $=$ Microporosity $; \mathrm{Bd}=$ Bulk density $; \mathrm{PR}=$ Soil penetration resistance according impact penetrometer; $\theta=$ Volumetric soil moisture corresponding to soil penetration resistance test. 


\subsection{Parameters Measured}

At 90 days after planting of sugarcane undisturbed soil samples were collected at different depths i.e. 0.00-0.10, $0.10-0.20,0.20-0.40 \mathrm{~m}$, for the assessment of LLWR and S index. Stainless steel rings were used with average diameter and height of 0.045 and $0.050 \mathrm{~m}$, respectively, making an average volume of $88 \mathrm{~cm}^{-3}$. These samples were saturated by water through gradual increase of water level until two-thirds of the ring height, and the weight of saturated samples were recorded.

Then, the samples were submitted to the following matric potentials: $-0.002,-0.008,-0.010 \mathrm{MPa}$ in the tension table; and $-0.033,-0.100,-0.500,-1.0$, and $-1.5 \mathrm{MPa}$ in Richard's chamber with porous plates (Dane \& Hopmans, 2002). When the samples reached hydraulic balance for each tension, their weight was recorded to determine their water content. Subsequently, penetration resistance was determined in the laboratory using a Marconi MA-933 bench top electronic penetrometer (Marconi, Piracicaba, São Paulo, Brazil) with constant speed of $1.0 \mathrm{~cm} \mathrm{~min}^{-1}$. This device was equipped with a $200-\mathrm{N}$ load cell; rod with cone (base diameter of $4.0 \mathrm{~mm}$ ) and half angle of $30^{\circ}$; and receiver and interface coupled with a microcomputer to record the data using the equipment's software.

Finally, the samples were oven-dried at about $105{ }^{\circ} \mathrm{C}$ for 24 hours, until constant weight was reached. Soil volumetric water content was determined as the ratio of the volume of water removed from the sample in each tension over soil volume of each sample. Bulk density was determined as the weight of dry soil divided by the total ring volume (Embrapa, 2017).

Intermediary values needed to estimate LLWR were(i) soil moisture at field capacity $\left(\theta_{\mathrm{FC}}\right)$, (ii) soil moisture at permanent wilting point $\left(\theta_{\mathrm{PWP}}\right)$, (iii) soil moisture at $0.10 \mathrm{~m}^{3} \mathrm{~m}^{-3}$ air-filled porosity $\left(\theta_{\mathrm{AP}}\right)$ was, and (iv) soil moisture at $2.5 \mathrm{MPa}$ soil penetration resistance $\left(\theta_{\mathrm{PR}}\right)$ as proposed by Severiano et al. (2011), Gonçalves et al. (2014), Guimarães Júnnyor et al. (2015).

The soil penetration resistance (PR) curve was fitted using the non-linear model recommended by Busscher (1990), as follows (Equation 1). The volumetric moisture was obtained by Topp and Ferré (2002) method.

$$
\mathrm{PR}=\mathrm{a} \cdot \mathrm{Bd}^{\mathrm{b}} \cdot \theta^{\mathrm{c}}
$$

where, $\mathrm{PR}$ is the soil penetration resistance (MPa); $\mathrm{Bd}$ is the soil bulk density $\left(\mathrm{Mg} \mathrm{m}^{-3}\right) ; \theta$ represents the volumetric water content $\left(\mathrm{m}^{3} \mathrm{~m}^{-3}\right)$; and $\mathrm{a}, \mathrm{b}$ and $\mathrm{c}$ represent the coefficients of the model.

The functional relation between the matric potential and volumetric water content, considering the soil moisture at field capacity (matric potential of $-0.01 \mathrm{MPa}$ ) and at permanent wilting point (matric potential of $-1.5 \mathrm{MPa}$ ), was fitted to the model proposed by Silva et al. (1994), according to Equation 2:

$$
\theta=\exp (\mathrm{d}+\mathrm{e} \cdot \mathrm{Bd}) \cdot \psi^{\mathrm{f}}
$$

where, $\theta$ is the volumetric water content $\left(\mathrm{m}^{3} \mathrm{~m}^{-3}\right), \psi$ is the matric potential (MPa); Bd is the soil bulk density (Mg $\left.\mathrm{m}^{-3}\right)$; $\mathrm{d}$, e and f represent the coefficients of the model.

$\theta_{\mathrm{AP}}$ was the difference between the volumetric water content at saturation and the air-filled porosity of $0.10 \mathrm{~m}^{3}$ $\mathrm{m}^{-3}$, taken as restrictive to the plant growth using Equation 3:

$$
\theta_{\mathrm{AP}}=\mathrm{TP}-0.1
$$

where, $\theta_{\mathrm{AP}}$ is the volumetric water content $\left(\mathrm{m}^{3} \mathrm{~m}^{-3}\right)$ for an aeration porosity of $0.10 \mathrm{~m}^{3} \mathrm{~m}^{-3}$; TP is the total porosity $\left(\mathrm{m}^{3} \mathrm{~m}^{-3}\right)$ as described by Blake and Hartge (1986).

The method described by Silva et al. (1994) and Tormena et al. (1998) was used to determine the LLWR, being considered as the difference between the upper and lower water range limits. The upper limit can be associated to $\theta_{\mathrm{FC}}$ which is the soil moisture when the air-filled porosity is less than $10 \%$. The lower limit can be associated to the soil water content in which the SR value is greater than $2.5 \mathrm{MPa}$, or to the $\theta_{\mathrm{PwP}}$. The critical bulk density value $\left(\mathrm{Bd}_{\mathrm{c}}\right)$ when LLWR is zero was defined as the intersection of the equations that determine the upper and lower LLWR values.

The S index was calculated using Equation 4, which was formulated by Dexter (2004) and, which uses as a base the adjustment parameters by Van Genuchten (1980) model.

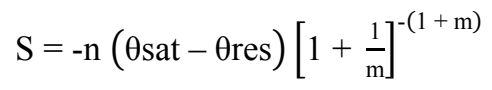

where, $\mathrm{S}$ is the value of the slope of the soil water retention curve at its inflection point; $\theta$ res is the residual water content $\left(\mathrm{m}^{3} \mathrm{~m}^{-3}\right)$; $\theta$ sat is the saturated water content $\left(\mathrm{m}^{3} \mathrm{~m}^{-3}\right) ; \mathrm{m}$ and $\mathrm{n}$ represent empirical parameters of the equation. 


\subsection{Statistical Analyses}

The adjustments of the equations of the water retention curves and the soil penetration resistance curves were performed by the linear regression method with the PROC REG routine, through the SAS program (SAS Institute, 2004).

\section{Results and Discussion}

\subsection{Least Limiting Water Range}

The LLWR was greater for clayey soil than for medium-textured soil. Also, cover crop effectively increased the LLWR in both soils (average incremental rate of $105 \%$ for clayey and $100 \%$ for medium-textured soil). Minimum tillage improved soil physical quality only when there was cover crop. Moreover, soil penetration resistance $\left(\theta_{\mathrm{PR}}\right)$ was a key factor in determining the LLWR independent of soil texture. The LLWR presented in Figure 1 demonstrated the differences among soil types and in Figure 2 the differences between treatments. There, it is also possible to observe the impact of the LLWR on other soil properties, i.e., $\theta_{\mathrm{PR}}, \theta_{\mathrm{AP}}, \theta_{\mathrm{FC}}$ and $\theta_{\mathrm{PwP}}$; therefore, it was possible to make predictions of possible effects of a soil management system on such properties and their effect on the LLWR.
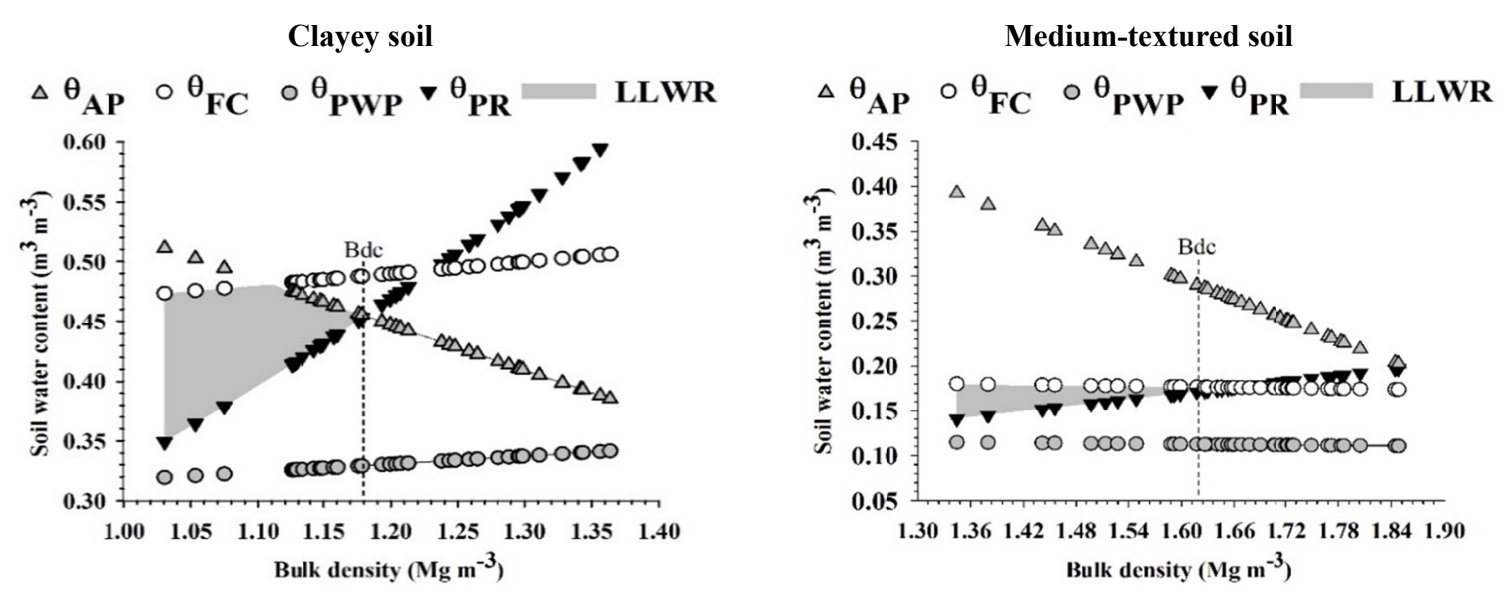

Figure 1. Variation in soil water content $(\theta)$ with the increase in bulk density $(\mathrm{Bd})$ for both studied soils $(0.00-0.40$ $\mathrm{m}$ ), in the critical limits of field capacity ( $\mathrm{FC}, \psi=-0.010 \mathrm{MPa}$ ), permanent wilting point (PWP, $\psi=-1.5 \mathrm{MPa}$ ), aeration porosity $\left(\mathrm{AP}=0.10 \mathrm{~m}^{-3} \mathrm{~m}^{-3}\right)$ and penetration resistance $(\mathrm{PR}=2.5 \mathrm{MPa})$

Note. $\mathrm{Bd}_{\mathrm{c}}=$ critical bulk density.


Figure 2. The least limiting water range (LLWR) as a function of density for both studied soils and their respective treatments

Note . $\mathrm{CCCT}=$ cover crop with conventional tillage $\mathrm{FCT}=$ fallow with conventional tillage CCMT $=$ cover crop with minimum tillage; FMT $=$ fallow with minimum tillage. 
The critical limits of the LLWR for studied soils are shown in Figure 1. The values of critical limits used in this study were as follows: field capacity $=-0.010 \mathrm{MPa}$, permanent wilting point $=-1.5 \mathrm{MPa}$, aeration porosity $=0.10$ $\mathrm{m}^{-3} \mathrm{~m}^{-3}$ and penetration resistance $=2.5 \mathrm{MPa}$, in which the hatched area corresponds to the LLWR. Each soil showed different range of the LLWR, which was due to different soil texture. Soils with higher clay content are characterized by higher water retention due to the aggregation of clay particles: intra-aggregate pores increase the volume of pore space, mainly pores with reduced diameter (Brady \& Weil, 2008). In agreement with this statement, Severiano et al. (2011) reported a strong influence of the soil texture on the LLWR, where the increase of the clay content, further the development of textured pores, which, in turn, influences the soil retention water and soil aeration.

For the clayey soil, the lower limit was determined by $\theta_{\mathrm{PR}}$ and the upper limit by $\theta_{\mathrm{FC}}$, up to $\mathrm{Bd}=1.13 \mathrm{Mg} \mathrm{m}^{-3}$. Thereafter, the upper limit of the LLWR for this soil was determined by $\theta_{\mathrm{AP}}$. These results demonstrate that up to $1.13 \mathrm{Mg} \mathrm{m}^{-3}$ the soil structure is appropriate. However, for Bd equal or higher than $1.13 \mathrm{Mg} \mathrm{m}^{-3}$, problems related to anoxia triggered by degradation of soil structure can be expected. Our results corroborate those found by Lima et al. (2012), who observed $\theta_{\mathrm{FC}}$ as the upper limit, up to $\mathrm{Bd}=1.14 \mathrm{Mg} \mathrm{m}^{-3}$ in Hapludox with pasture. The same authors have reported that up to this Bd value the microstructure was stable and preserved, and the pore space was enough for gas exchange. For higher values, however, a reduction of macropores volume was observed.

It was also observed in Figure 1 that an increase in Bd correlated positively with $\theta_{\mathrm{PR}}$ and negatively with $\theta_{\mathrm{AP}}$ in clayey soil, indicating that an increase in Bd decreased the LLWR as a function of both the upper limit and lower limit. In addition, for the medium-textured soil, only $\theta_{\mathrm{PR}}$ (the lower limit) and $\theta_{\mathrm{FC}}$ (the upper limit) were the limiting variables responsible for restricting the LLWR.

The role of $\theta_{\mathrm{PR}}$ as the lower limit of the LLWR can be observed for both studied soils, hence demonstrating its direct effect on soil physical properties. High $\theta_{\mathrm{PR}}$ restricts the range of water availability for root growth and development. These results are aligned with previous studies that indicated that $\theta_{\mathrm{PR}}$ is the main variable associated with the reduction of soil physical quality resulting in a reduction of LLWR (Tormena et al., 1998; Betioli Júnior et al., 2012; Araujo et al., 2013). Restriction of roots penetration by compacted soil layers may have severe effects on plant growth if the surface soil dries and water supply to the plants is limited by the inability of the roots to tap reserves of water in the subsoil (Materechera et al., 1992). Otto et al. (2011) analyzed the relationship between the spatial distribution of physical soil properties and sugarcane root density in a mechanically harvested area and observed that sugarcane root growth was not affected below PR values of $0.75 \mathrm{MPa}$, but was decreased significantly between 0.75 and 2.0 MPa. Yet in accordance with these authors, sugarcane root growth was severely restricted when PR $>2.0 \mathrm{MPa}$.

The LLWR ranged from 0.00 to $0.124 \mathrm{~m}^{3} \mathrm{~m}^{-3}$ for the clayey soil and from 0.00 to $0.040 \mathrm{~m}^{3} \mathrm{~m}^{-3}$ for the medium-textured soil (Figure 2). This range is in the same order of magnitude of studies performed in tropical conditions in Brazil. For example, Cavalieri et al. (2011) observed LLWR values ranging from $0.082-0.122 \mathrm{~m}^{3} \mathrm{~m}^{-3}$ for clayey soil and $0.000-0.094 \mathrm{~m}^{3} \mathrm{~m}^{-3}$ for a medium-textured soil. Prado et al. (2017) evaluated the soil structural quality after the use of cover crops under no-tillage during the sugarcane crop reformation period in a clayey soil and observed that the LLWR varied between $0.00-0.09 \mathrm{~m}^{3} \mathrm{~m}^{-3}$ and between $0.00-0.10 \mathrm{~m}^{3} \mathrm{~m}^{-3}$ in depth of $0.15 \mathrm{~m} \mathrm{e}$ $0.25 \mathrm{~m}$, respectively.

Soil $\mathrm{Bd}_{\mathrm{c}}$ was found to be 1.18 and $1.65 \mathrm{Mg} \mathrm{m}^{-3}$ for clayey and medium-textured soils, respectively. Values of $\mathrm{Bd}_{\mathrm{c}}$ higher than these probably present limiting conditions to plant development despite the water content in the soil due to structural restrictions. Guimarães Júnnyor et al. (2015) evaluated physical quality of a oxisol (clay 44\%) and found $\mathrm{Bd}_{\mathrm{c}}$ of $1.36 \mathrm{Mg} \mathrm{m}^{-3}$. According to Petean et al. (2010), low $\mathrm{Bd}_{\mathrm{c}}$ increases the possibility of Bd achieving critical values $\left(\mathrm{Bd}>\mathrm{Bd}_{\mathrm{c}}\right.$ ), suggesting a higher incidence of limiting physical conditions for plant development. High Bd values suggest strongly restrictive conditions, mainly in low soil water levels, because they restrict the deepening of the roots, and in a situation of extreme deficits of water in the soil, result in plant water stress (Calonego, Borghi, \& Crusciol, 2011; Souza et al., 2015).

However, in the clayey soil $\mathrm{Bd}$ was lower than $\mathrm{Bd}_{\mathrm{c}}$ for all treatments, thus demonstrating good soil structure (Figure 2). The treatment MTCC stood out because it had lower Bd, so more soil micropores, and consequently wider LLWR. On the other hand, the MTF presented higher Bd and narrower LLWR. These results demonstrate a positive effect of cover crop on the LLWR during sugarcane replanting. Traditionally, no-tillage and minimum tillage systems demonstrate limitations related to superficial soil compaction due to natural arrangement of particles and in-field machinery traffic (Tormena et al., 2007). However, Vischi Filho et al. (2016) reported improvements of the LLWR in sugarcane rows under minimum tillage with crop succession after the third sugarcane cropping cycle. The same authors pointed out that sugarcane straw deposited on the soil after 
mechanical harvest helped restore soil structure, increases soil water retention, and the range of soil water without limitations to root development of sugarcane.

In the medium-textured soil, the treatment with fallow presented higher $\mathrm{Bd}\left(1.67 \mathrm{Mg} \mathrm{m}^{-3}\right)$ in FCT than FMT $(1.71$ $\left.\mathrm{Mg} \mathrm{m}^{-3}\right)$. These values were greater than $\mathrm{Bd}_{\mathrm{c}}\left(\mathrm{Bd}_{\mathrm{c}} \geq 1.65 \mathrm{Mg} \mathrm{m}^{-3}\right)$, consequently the LLWR becomes zero for these treatments Leão et al. (2006) affirmed that it is hard to foresee the impact of the LLWR $=0$ on plant growth and development, since there are several physiological and/or morphological processes involved, and there are plant species which can adapt and grow under stress conditions. Gonçalves et al. (2014) reported adaptation to soil compaction called the pot effect because plant roots are concentrated in a small volume of soil due to restrictive conditions for root development. The analysis of the LLWR in the soil profile presented in Figures 3 and 4 confirms this performance.
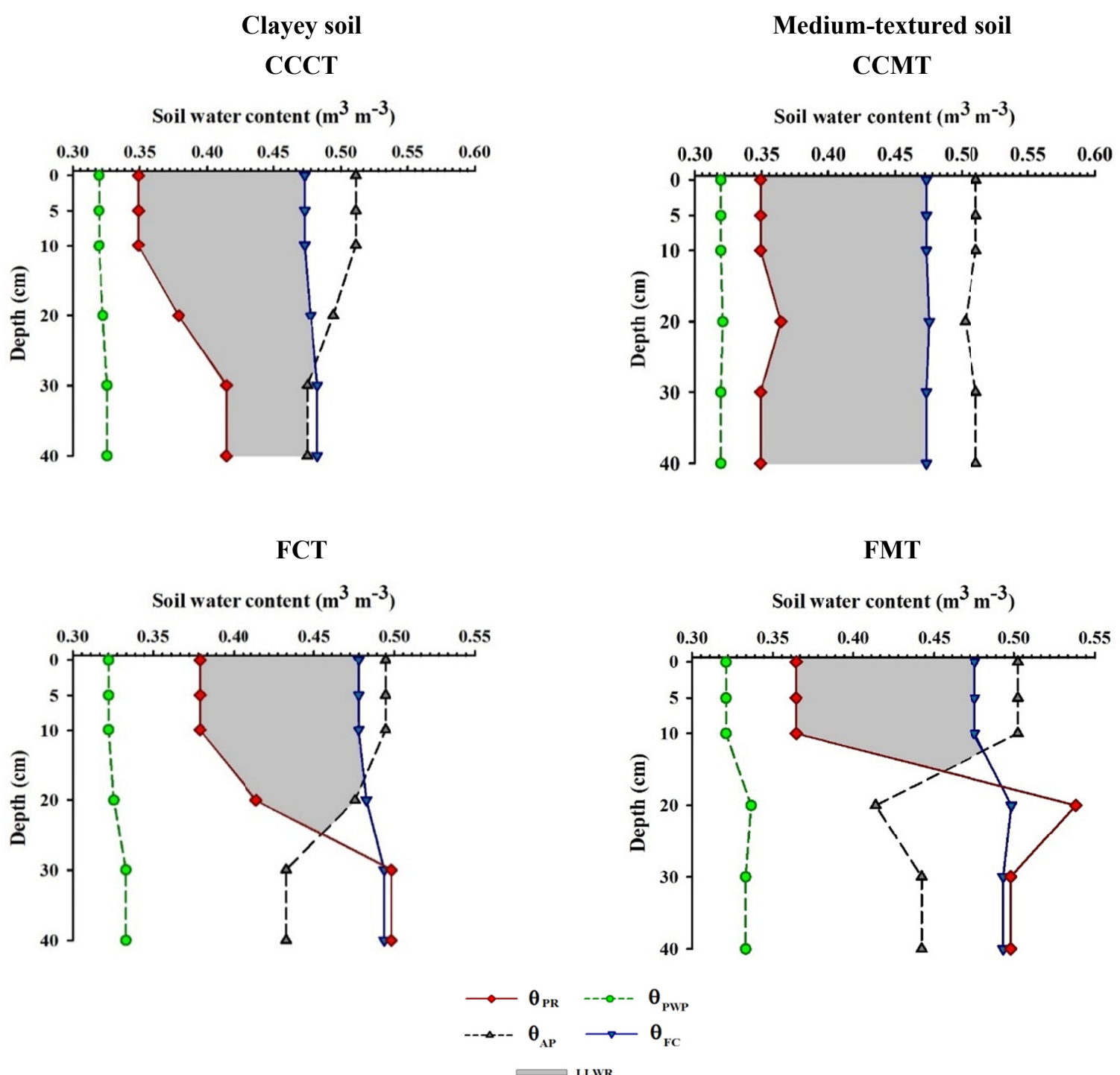

Figure 3. The least limiting water range (LLWR) variations for different layers in the clayey soil and respective treatments

Note. CCCT $=$ cover crop with conventional tillage; $\mathrm{FCT}=$ fallow with conventional tillage CCMT = cover crop with minimum tillage; $\mathrm{FMT}=$ fallow with minimum tillage. 


\section{Clayey soil}

CCCT

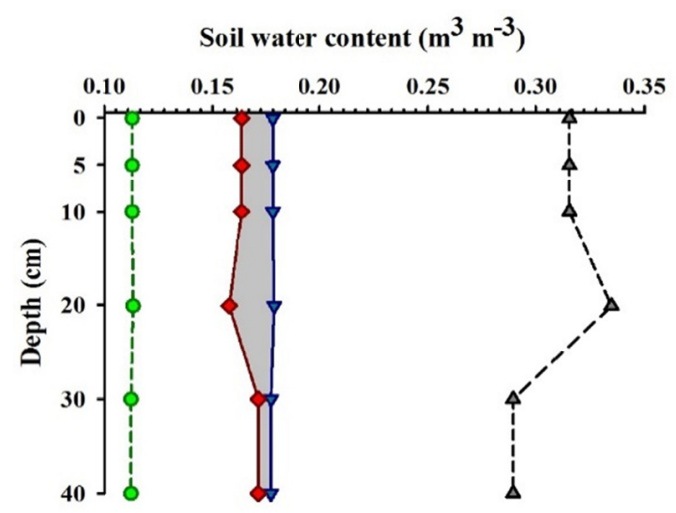

FCT

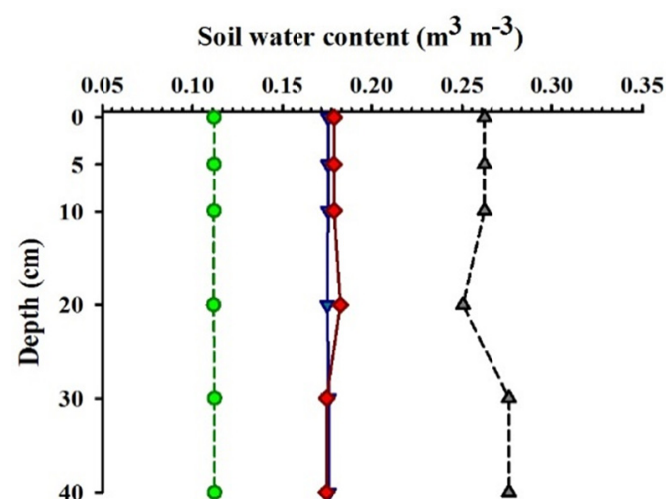

\section{Medium-textured soil}

CCMT

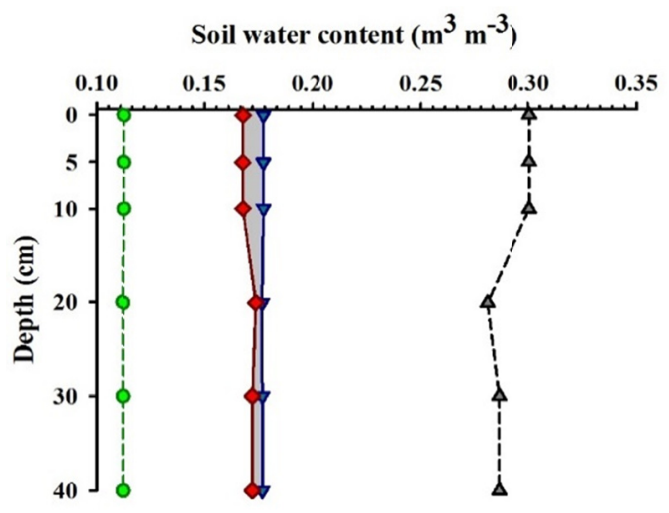

FMT

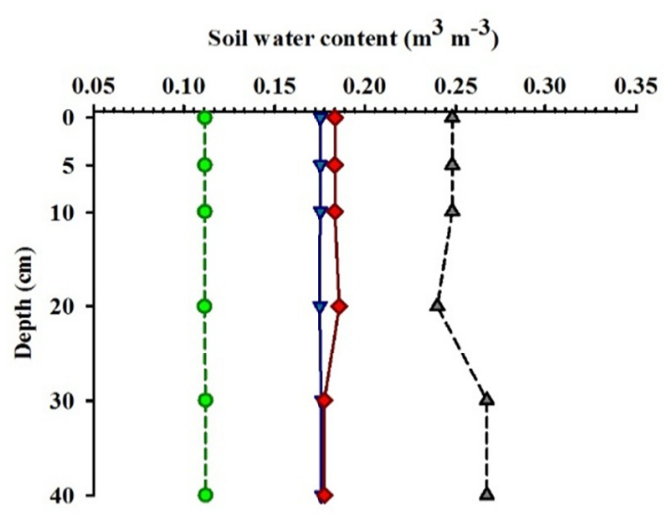

$$
\begin{aligned}
& \because \theta_{\mathrm{PR}} \quad \cdots-\theta_{\mathrm{PWP}} \\
& -\triangle-\theta_{\mathrm{AP}} \longrightarrow \theta_{\mathrm{FC}}
\end{aligned}
$$

Figure 4. The least limiting water range (LLWR) variations for different layers in the medium-textured soil and respective treatments

Note. CCCT $=$ cover crop with conventional tillage; FCT $=$ fallow with conventional tillage; $\mathrm{CCMT}=$ cover crop with minimum tillage; FMT $=$ fallow with minimum tillage.

For clayey soil, the treatment with cover crop did not present limitation of the LLWR throughout the soil profile $(0.00-0.40 \mathrm{~m})$. However, the treatment with fallow presentenced limitations of the LLWR, which were $0.25 \mathrm{~m}$ deep for FCT and $0.15 \mathrm{~cm}$ deep for FMT caused by high $\theta_{\mathrm{PR}}$ and low $\theta_{\mathrm{AP}}$. These results indicated the presence of more compacted layers, which was a sign of structural limitation. Severiano et al. (2011) highlight that low soil compaction is beneficial to plant growth due to increased water retention as a function of higher microporosity. This characteristic is desirable especially during dry periods and in soils with low capacity for water retention. However, severe conditions related to soil compaction may easily compromise plant growth and crop productivity. In a study evaluating four levels of soil compaction caused by agricultural machinery, Gonçalves et al. (2014) observed an alteration of the LLWR caused by progressive increase in soil compaction, reducing the LLWR to almost zero in the $0.00-0.10 \mathrm{~m}$ layer in a treatment with 20 tractor passes in the inter-row of sugarcane crop.

Despite the medium-textured soil a narrower range of the LLWR than for the clayey soil, the LLWR was not null down to $0.40 \mathrm{~m}$ in treatments with cover crop. However, in treatments with fallow, the value of LLWR was zero in the whole soil profile, because the lower limit was higher than the upper limit $(\theta \mathrm{PR}>\theta \mathrm{FC})$, indicating severe soil structural degradation. Tormena et al. (2007) highlight that cover crop is one of the fundamental contributor to soil quality and sustainability. Thus, this management strategy should be employed because it efficiently controls 
superficial compaction. These authors also observed better soil water retention under no-till with cover crop, which temporarily lead to higher levels of the LLWR.

The LLWR was found wide for most treatments in the surface layers. Lima et al. (2012) also observed broader LLWR in the surface layers $(0-0.05 \mathrm{~m})$ than in deeper layers $(0.20-0.25 \mathrm{~m})$, in which values of 0.149 and $0.132 \mathrm{~m}^{3}$ $\mathrm{m}^{-3}$, respectively. The same authors attribute this fact to high biological activity (root system and microorganism activity) in these layers, which probably strengthen the biopores formation with a widely varied size distribution. In addition, cover crop increased the level of crop residues on the soil surface, consequently changing physical characteristics directly related to the LLWR.

\subsection{S Index Analysis}

The $\mathrm{S}$ index analysis (Figure 5) shows that treatments with cover crop, independent of soil texture, presented in average, higher S index ( 0.071 and 0.054 for clayey and medium-textured soil, respectively) than with fallow ( 0.062 and 0.049 for clayey and medium-textured soil, respectively). Moreover, higher S index was recorded for clayey soil (average $S$ index $=0.066$ ) compared to that obtained in medium-textured soil (average $S$ index $=0.051$ ), indicating stronger presence of structural pores in the clayey soil, whereas textural porosity prevailed in the medium-textured soil. According to Dexter (2004), soil drying between saturation and inflection point is governed mainly by the emptying of structural pores. Therefore, higher $\mathrm{S}$ index is related to the presence of structural pores.

Clayey soil

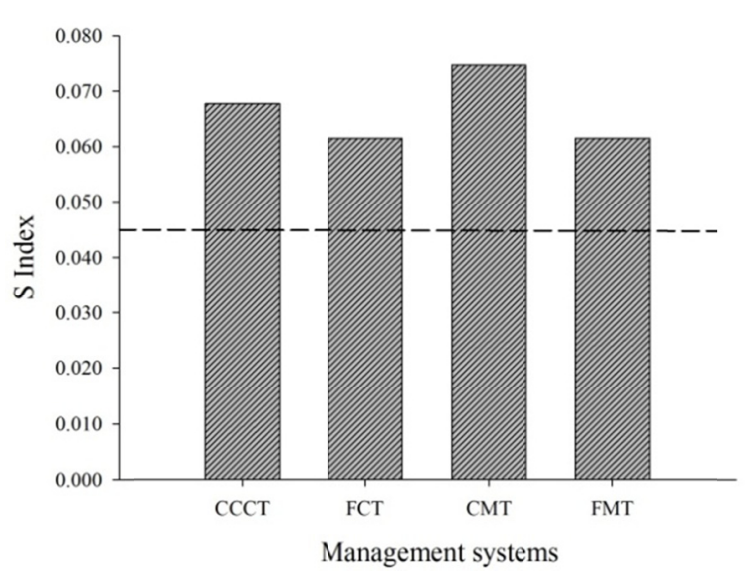

Medium-textured soil

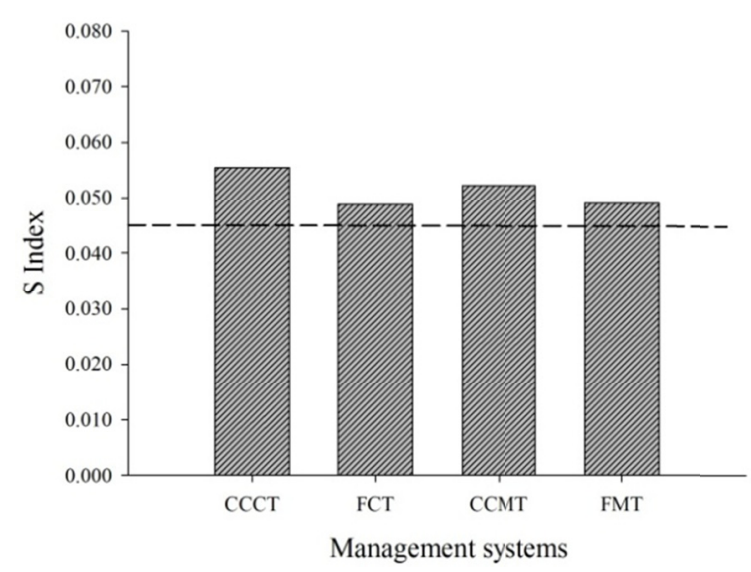

Figure 5. $S$ index for both soils and their respective treatments

Note. $\mathrm{CCCT}=$ cover crop with conventional tillage; $\mathrm{FCT}=$ fallow with conventional tillage; $\mathrm{CCMT}=$ cover crop with minimum tillage; FMT = fallow with minimum tillage.

The limiting value without any sudden change in soil properties for $S$ index is about 0.035 , while $S$ index $<0.020$ indicates degraded soil (Dexter, 2004). However, Andrade \& Stone (2009), studying Brazilian Cerrado soils determined the limiting $S$ index $=0.045$ as appropriate to distinguish good quality soils from soils with tendency to degradation; whereas $S \leq 0.025$ denotes extremely degraded soils. In our study, none of the evaluated treatments demonstrated values below the threshold considered critical for physical soil degradation $(S=0.045)$ mentioned by Andrade and Stone (2009). However, values very close to this limit were found in the medium-textured soil, especially in treatments with fallow. Therefore, the use of cover crop in this soil is necessary to maintain, or even improve, soil physical conditions throughout sugarcane cropping cycles.

\section{Conclusions}

Clayey soil and medium-textured soil are sensitive to the management systems used, where the use of cover crop promotes an elevation of LLWR and $\mathrm{S}$ index. Furthermore, the fallow, was found to restrict the growth/development of sugarcane due to the degradation of the soil structure. In addition, minimum tillage during the sugarcane replanting period preserved or even improved physical soil quality when it is associated with cover crop. Finally, both soils show good physical quality by the S index during the first cycle of sugarcane cultivation. 


\section{Acknowledgments}

We thank the Support São Paulo Research Foundation (grant numbers: 2013/21696-3) for granting a scholarship and the São Martinho Group and Itaquerê Group, for providing the study area.

\section{References}

Andrade, R. S., \& Stone, L. F. (2009). Índice S como indicador da qualidade física de solos do cerrado brasileiro. Revista Brasileira de Engenharia Agrícola e Ambiental, 13, 382-388. https://doi.org/10.1590/S1415-4366 2009000400003

Araújo, F. S., Souza, Z. M., Souza, G. S., Matsura, E. E., \& Barbosa, R. S. (2013). Espacialização do intervalo hídrico ótimo de um Latossolo Vermelho em dois sistemas de colheita de cana-de-açúcar. Pesquisa Agropecuária Brasileira, 48, 651-660. https://doi.org/10.1590/S0100-204X2013000600011

Betioli Júnior, E., Moreira, W. H., Tormena, C. A., Ferreira, C. J. B., Silva, A. P., \& Giarola, N. F. P. (2012). Intervalo Hídrico ótimo e grau de compactação de um latossolo vermelho após 30 anos sob plantio direto. Revista Brasileira de Ciência do Solo, 36, 971-982. https://doi.org/10.1590/S0100-06832012000300027

Blake, G. R., \& Hartge, K. H. (1986). Bulk density. In A. Klute (Ed.). Methods of soil analysis (2nd ed., pp. 363-375). Madison: ASA/SSSA.

Brady, N. C., \& Weil, R. R. (2008). The nature and properties of soils (14th ed.). New Jersey: Prentice Hall.

Busscher, W. J. (1990). Adjustment of flat-tipped penetrometer resistance data to a common water content. Transactions of the American Society of Agricultural Engineers, 33, 519-524. https://doi.org/10.13031/2013. 31360

Calonego, J. C., Borghi, E., \& Crusciol, C. A. C. (2011). Intervalo hídrico ótimo e compactação do solo com cultivo consorciado de milho e braquiária. Revista Brasileira de Ciência do Solo, 35, 2183-2190. https://doi.org/10.1590/S0100-06832011000600033

Cavalieri, K. M. V., Carvalho, L. A., Silva, A. P., Libardi, P. L., \& Tormena, C. A. (2011). Qualidade física de três solos sob colheita mecanizada de cana-de-açúcar. Revista Brasileira de Ciência do Solo, 35, 1541-1549. https://doi.org/10.1590/S0100 -06832011000500008

CONAB (Companhia Nacional de Abastecimento). (2018). Acompanhamento de safra brasileira: Cana-de-açúcar. Quarto Levantamento-Safra 2017/18 (p. 73). Brasília, Brazil.

Cortez, L. A. B. (2010). Bioetanol de Cana-de-Açúcar. São Paulo: Edgard Blücher Ltda.

Dane, J. H., \& Hopmans, J. W. (2002). Pressure plate extractor. In J. H. Dane, \& C. Topp (Eds.), Methods of soil analysis: Physical methods (pp. 699-690). Madison, Soil Science Society of America/American Society of Agronomy.

Dexter, A. R. (2004) Soil physical quality. Part I. Theory, effects of soil texture, density, and organic matter, and effects on root growth. Geoderma, 120, 201-214. https://doi.org/10.1016/j.geoderma.2003.09.004

Embrapa (Empresa Brasileira de Pesquisa Agropecuária). (2017). Centro Nacional de Pesquisa de Solos. Manual de métodos de análise de solos (3rd ed., p. 573). Brasilia, DF: EMBRAPA.

Gonçalves, W. G., Severiano, E. C., Silva, F. G., Costa, K. A. P., Guimarães Junnyor, W. S., \& Melo, G. B. (2014). Least limiting water range in assessing compaction in a Brazilian Cerrado latosol growing sugarcane. Revista Brasileira de Ciência do Solo, 38, 432-443. https://doi.org/10.1590/S0100-06832014000200008

Guedes Filho, O., Blanco-Canqui, H., \& Silva, A. P. (2013). Least limiting water range of the soil seedbed for long-term tillage and cropping systems in the central Great Plains, USA. Geoderma, 207-208, 99-110. https://doi.org/10.1016/j.geoderma.2013.05.008

Guimarães Júnnyor, W. S., Severiano, E. C., Silva, A. G., Gonçalves, W. G., Andrade, R., Martins, B. R. R., \& Custódio, G. D. (2015). Sweet Sorghum Performance affected by soil Compaction and sowing time as a second crop in the Brazilian Cerrado. Revista Brasileira de Ciencia do Solo, 39, 1744-1754. https://doi.org/ 10.1590/01000683rbcs20150121

Leão, T. P., Silva, A. P., Macedo, M. C. M., Imhoff, S., \& Euclides, V. P. B. (2006). Least limiting water range: A potential indicator of changes in near-surface soil physical quality after the conversion of Brazilian Savanna into pasture. Soil and Tillage Research, 88, 279-285. https://doi.org/10.1016/j.still.2005.06.014 
Lima, V. M. P., Oliveira, G. C., Serafim, M. E., Curi, N., \& Evangelista, A. R. (2012). Intervalo Hídrico Ótimo como Indicador de melhoria da qualidade estrutural de latossolo degradado. Revista Brasileira de Ciência do Solo, 36, 71-78. https://doi.org/10.1590/S0100-06832012000100008

Materechera, S. A., Alston, A. M., Kirby, J. M., \& Dexter, A. R. (1992). Influence of root diameter on the penetration of seminal roots into a compacted subsoil. Plant Soil, 144, 297-303. https://doi.org/10.1007/ BF00012888

Neves, M. F., \& Trombin, V. G. (2014). A dimensão do setor Sucro energético: Mapeamento e quantificação da safra 2013/14. Ribeirão Preto: Markestrat, Fundace, FEA-RP/USP.

Otto, R., Silva, A. P., Franco, H. C. J., Oliveira, E. C. A., \& Trivelin, P. C. O. (2017). High soil penetration resistance reduces sugarcane root system development. Soil and Tillage Research, 117, 201-210. https://doi.org/10.1016/j.still.2011.10.005

Petean L. P., Tormena, C. A., \& Alves, S. J. (2010). Intervalo hídrico ótimo de um latossolo vermelho distroférrico sob plantio direto em sistema de integração lavoura-pecuária. Revista Brasileira de Ciência do Solo, 34, 1515-1526. https://doi.org/10.1590/S0100-06832010000500004

Prado, E. A. F., Vitorino, A. C. T., Garcia, R. A., \& Silva, C. J. (2017). Hydrophysical Quality of an Oxisol Under a No-tillage System with Alternative Crops to Renew a Sugarcane Field. Sugar Tech, 20, 135-142. https://doi.org/10.1007/s12355-017-0542-6

SAS Institute Inc. (2004). SAS/STAT ${ }^{\circledR} 9.1$ User's Guide. Cary, NC: SAS Institute Inc.

Severiano, E. C., Oliveira, G. C., Dias Júnior, M. S., Costa, K. A. P., Silva, F. G., \& Ferreira Filho, S. M. (2011). Structural changes in Latosols of the cerrado region: I Relationships between soil physical properties and least limiting water range. Revista Brasileira de Ciência do Solo, 35, 773-782. https://doi.org/10.1590/ S0100-06832011000300013

Silva, A. P., \& Kay, B. D. (1997). Estimating the Least Limiting Water Range of Soils from Properties and Management. Soil Science Society of America Journal, 61, 877-883. https://doi.org/10.2136/sssaj1997. $03615995006100030023 x$

Silva, A. P., Kay, B. D., \& Perfect, E. (1994). Characterization of the Least Limiting Water Range of Soils. Soil Science Society of America Journal, 58, 1775-1781. https://doi.org/10.2136/sssaj1994.0361599500580 $0060028 \mathrm{x}$

Soil Survey Staff. (2014). Keys to Soil Taxonomy. United States Department of Agriculture, Natural Resources Conservation Service, Washington, DC.

Souza, G. S, Souza, Z. M., Cooper, M., \& Tormena, C. A. (2015). Controlled traffic and soil physical quality of an Oxisol under sugarcane cultivation. Scientia Agricola, 72, 270-277. https://doi.org/10.1590/0103-9016-2 014-0078

Topp, G. C., \& Ferré, P. A. (2002). The soil solution phase. In J. H. Dane, \& G. C. Topp (Eds.), Methods of soil analysis (pp. 417-107). Wisconsin, Soil Science Society of America.

Tormena, C. A., Araújo, M. A., Fidalski, J., \& Costa, J. M. (2007). Variação temporal do intervalo hídrico ótimo de um latossolo vermelho distroférrico sob sistemas de plantio direto. Revista Brasileira de Ciência do Solo, 31, 211-219. https://doi.org/10.1590/S0100-06832007000200003

Tormena, C. A., Silva, A. P., \& Libardi, P. L. (1998) Caracterização do intervalo hídrico ótimo de um Latossolo Roxo sob plantio direto. Revista Brasileira de Ciência do Solo, 22, 573-581. https://doi.org/10.1590/S010006831998000400002

USDA (United States Department of Agriculture). (2017). Soil Science Division Staff. In C. Ditzler, K. Scheffe, \& H. C. Monger (Eds.), Soil survey manual. USDA Handbook 18. Government Printing Office, Washington, D.C.

Van Genuchten, M. T. (1980). A closed-form equation for predicting the hydraulic conductivity of unsaturated soils. Soil Science Society of America Journal, 44, 892-898. https://doi.org/10.2136/sssaj1980.036159950 04400050002x

Vischi Filho, O. J., Souza, Z. M., Souza, G. S., Sousa, A. C. M., \& Silva, R. B. (2016). Intervalo Hídrico Ótimo em área de cana-de-açúcar com diferentes ciclos de colheita mecanizada. Irriga, Edição Especial, Grandes Culturas, 96-108. 


\section{Copyrights}

Copyright for this article is retained by the author(s), with first publication rights granted to the journal.

This is an open-access article distributed under the terms and conditions of the Creative Commons Attribution license (http://creativecommons.org/licenses/by/4.0/). 